\title{
Phase I study of temozolomide plus paclitaxel in patients with advanced malignant melanoma and associated in vitro investigations
}

\author{
A Azzabi' ${ }^{1,2}$, AN Hughes', PM Calvert ${ }^{2}$, ER Plummer',2, R Todd ${ }^{1,2}$, MJ Griffin', MJ Lind ${ }^{3}$, A Maraveyas ${ }^{3}$, C Kelly ${ }^{2}$, \\ K Fishwick ${ }^{2}$, AH Calvert ${ }^{1,2}$ and AV Boddy*,1
}

'Northern Institute for Cancer Research, University of Newcastle, Newcastle upon Tyne NE2 4HH, UK; ${ }^{2}$ Northern Centre for Cancer Treatment, Newcastle General Hospital, Newcastle upon Tyne, UK; ${ }^{3}$ Academic Department of Oncology, The Princess Royal Hospital, Hull, UK

\begin{abstract}
The purpose of this study was to determine activity of temozolomide combined with paclitaxel or epothilone B in vitro, and to investigate the combination of temozolomide with paclitaxel in a Phase I clinical trial. Melanoma cell lines A375P and DX3 were treated with temozolomide and either paclitaxel or epothilone B. Combination indices were determined to assess the degree of synergism. In a clinical study, 2 I patients with malignant melanoma were treated with increasing doses of temozolomide (orally, days I-5), in combination with a fixed dose of paclitaxel (i.v. infusion day I), followed by dose escalation of the latter drug. Cycles of treatment were repeated every 3 weeks. Pharmacokinetics of both agents were determined on day I, with temozolomide pharmacokinetics also assessed on day 5. All three compounds were active against the melanoma cell lines, with epothilone B being the most potent. There was a strong degree of synergism between temozolomide and either paclitaxel or epothilone B. In the clinical study, no pharmacokinetic interaction was observed between temozolomide and paclitaxel. Dose escalation of both drugs to clinically active doses was possible, with no dose-limiting toxicities observed at $200 \mathrm{mg} \mathrm{m}^{-2}$ day ${ }^{-1}$ temozolomide and $225 \mathrm{mg} \mathrm{m}^{-2} \mathrm{day}^{-1}$ paclitaxel. There were two partial responses out of 15 evaluable patients. One patient remains alive and symptom-free at 4 years after treatment. Temozolomide and paclitaxel may be administered safely at clinically effective doses. Further evaluation of these
\end{abstract} combinations in melanoma is warranted.

British Journal of Cancer (2005) 92, 1006 - I012. doi:10.1038/sj.bjc.6602438 www.bjcancer.com

Published online 8 March 2005

(c) 2005 Cancer Research UK

Keywords: combination; pharmacokinetics; interaction; epothilone B

Stage IV melanoma carries a very poor prognosis (Balch et al, 2001) and a median survival of no more than 6-9 months. The 5year survival is at best $5-10 \%$ (Lotze et al, 2001). Several drugs have been used in the treatment of stage IV melanoma, including dacarbazine (DTIC), nitrosoureas, platinum compounds and vinca alkaloids, with only modest success.

Paclitaxel $\left(\right.$ Taxol $^{\mathrm{TM}}$ ) is a member of the taxane group of antitumour agents. It was discovered in the early sixties by the National Cancer Institute (Rowinsky and Donehower, 1995). Early clinical studies indicated activity against a number of tumours including ovarian, breast, lung and melanoma (Rowinsky et al, 1990; Einzig et al, 1991b; Ettinger, 1993; Martin, 1993). Paclitaxel was first approved by the FDA in 1992 to be used as a second-line treatment for ovarian carcinoma (Arbuck et al, 1993). Against metastatic malignant melanoma, paclitaxel has a response rate of 18-20\% (Legha et al, 1990; Einzig et al, 1991a; Wiernik and Einzig, 1993). Paclitaxel exerts its antitumour activity by binding to the $\beta$

*Correspondence: Dr AV Boddy; E-mail: alan.boddy@ncl.ac.uk Received II October 2004; revised 10 January 2005; accepted II January 2005; published online 8 March 2005 subunit of tubulin (Horwitz, 1994) and stabilising microtubules. The mechanisms by which cells become resistant to paclitaxel are thought to be either due to mutations in tubulin or to overexpression of drug efflux pumps such as MDR1. The main toxicities associated with paclitaxel are: hypersensitivity reactions, neutropaenia and peripheral neuropathy, usually sensory.

Temozolomide $\left(\right.$ Temodal $^{\mathrm{TM}}$ ) is an oral alkylating agent, related to DTIC. After administration, temozolomide spontaneously decomposes to 5-(3-methyltriazen-1-yl)imidazole-4-carboxamide (MTIC), which then yields AIC and methyl diazonium (Denny et al, 1994). The latter alkylates DNA, primarily at the $O^{6}$ of guanine. Bioavailability of temozolomide is nearly $100 \%$ when administered orally, with good distribution to tissue (Baker et al, 1999; Brada et al, 1999). Activity has been demonstrated against a number of tumours (Bleehen et al, 1995; Dhodapkar et al, 1997; Middleton et al, 2000b). In malignant melanoma, activity was comparable to that of dacarbazine (Middleton et al, 2000a, b).

Cancer cells may acquire resistance to temozolomide by a number of mechanisms, including overexpression of $O^{6}$-alkylguanine-DNA alkyltransferase (Lee et al, 1994; Middleton et al, 1998), deficiency or mutation in the mismatch repair (MMR) pathway (D'Atri et $a l, 1998$ ) and increased expression of proteins that 
inhibit apoptosis, such as Bcl-2 (Selzer et al, 1998). Temozolomide is well tolerated (Newlands et al, 1992; O'Reilly et al, 1993; Bleehen et al, 1995; Dhodapkar et al, 1997), with thrombocytopaenia as the main toxicity. This is usually self-limiting and most patients recover by day 28 .

Individually, paclitaxel and temozolomide have modest activity against metastatic malignant melanoma. As they have different mechanisms of action, nonoverlapping toxicities and differing mechanisms of resistance, the combination of paclitaxel and temozolomide has been investigated in a Phase I study in melanoma patients. In addition to the clinical trial, in vitro growth inhibition studies were performed with the combination of temozolomide and either paclitaxel or epothilone B, a novel antimicrotubule compound (Rothermel et al, 2003).

\section{METHODS}

\section{In vitro studies}

Two melanoma cell lines, A375P and DX3, were cultured using RPMI 1640 culture medium with L-glutamine supplemented with $10 \%$ foetal calf serum and penicillin/streptomycin in $5 \% \mathrm{CO}_{2}$ incubators at $37^{\circ} \mathrm{C}$. Cells were exposed to varying concentrations of temozolomide, paclitaxel or epothilone B individually for three doubling times and $\mathrm{IC}_{50}$ values determined in triplicate using the SRB assay.

Drug combination studies were conducted on each cell line using either temozolomide plus paclitaxel or temozolomide plus epothilone B. In each case, cells were exposed to the two agents simultaneously. Drug concentrations used in combination were at
$3,1,0.3,0.1,0.01$ times the $\mathrm{IC}_{50}$ concentration for each drug. Data were analysed using the Calcusyn software and the method of Chou and Hayball (1996). The combination index (CI) for each drug combination was calculated, where $\mathrm{CI}=1$ denotes an additive effect, $\mathrm{CI}<1$ indicates synergy and $\mathrm{CI}>1$ suggests antagonism of effect.

\section{Clinical study}

The primary objectives of the study were to determine the maximum tolerated dose of the combination of paclitaxel and temozolomide, and to identify the haematological and nonhaematological toxicities of the combination. Secondary objectives were to determine the response rate and response duration from the combination, and to determine the pharmacokinetics of temozolomide and paclitaxel when given in combination.

Adult patients with a diagnosis of stage IV melanoma were included. All were chemotherapy naïve, with no clinical evidence of CNS metastases, WHO performance status of $0-2$, a life expectancy of at least 12 weeks and adequate haematological, renal and hepatic function. Patients had at least one measurable lesion. All patients signed an informed consent form prior to participating in the trial, which was approved by the ethics committee of the Newcastle Hospitals Trust and of the Medical School, University of Kingston upon Hull. All patients had prestudy biochemical, clinical and radiological assessments before receiving the first cycle of chemotherapy and subsequently during the study. Toxicities were assessed using the Common Toxicity Criteria (Version 2.0).

Dose levels for the study were predefined as in Figure 1; however, intermediate dose levels were allowed. Paclitaxel was

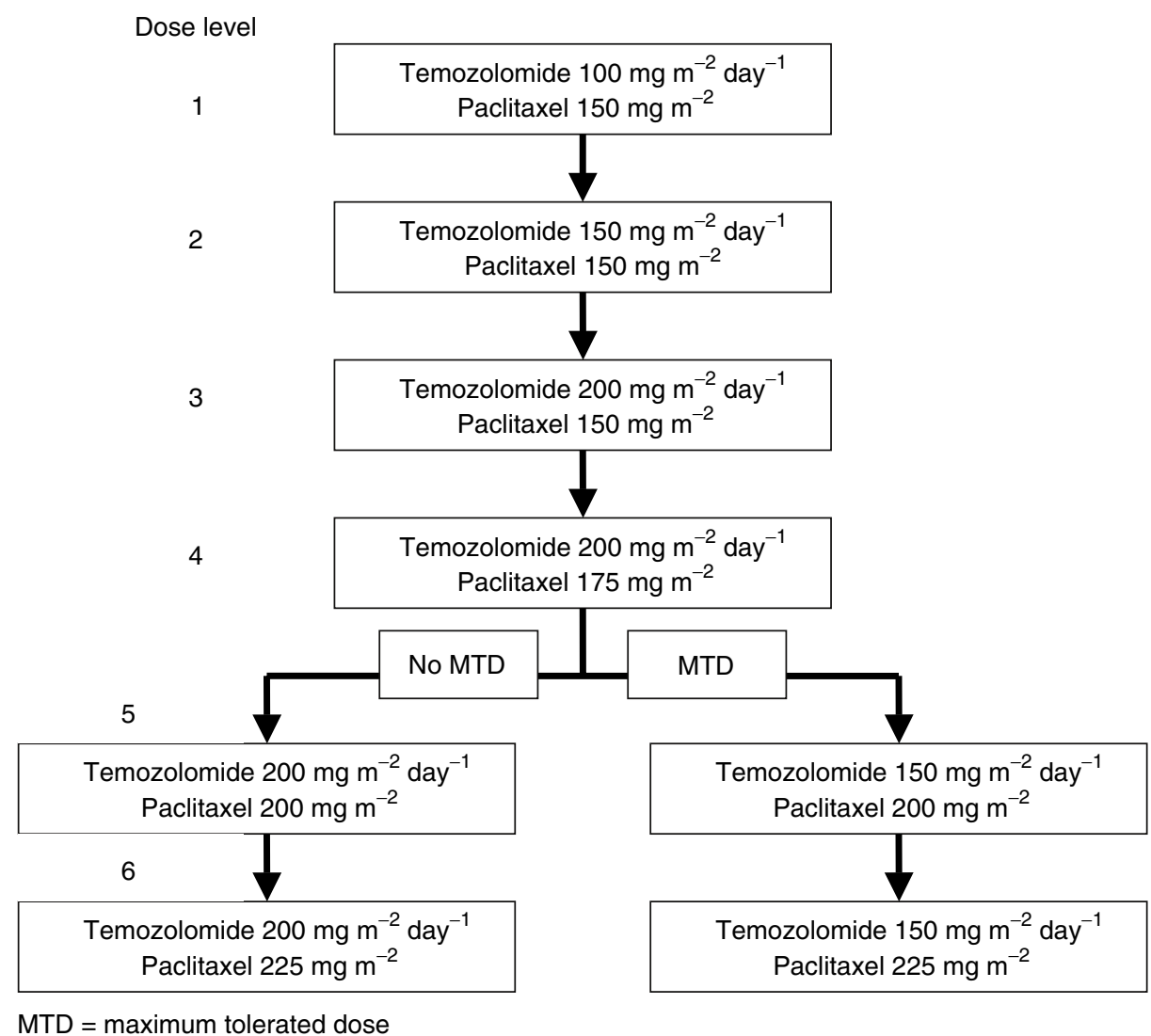

Figure I Dose escalation scheme, indicating daily dose of temozolomide, given on each of 5 consecutive days. Dose of paclitaxel administered on day I. The dose levels used in the current study are indicated by number. Dose level 4 represents full therapeutic doses of each agent. After dose level 4 , subsequent dose changes depended on the occurrence of dose-limiting toxicities to define the maximum tolerated dose (MTD). 
administered intravenously as a 3-h infusion on day one of each cycle. Standard premedications were used to prevent hypersensitivity reactions. Temozolomide was given orally on the morning of days $1-5$ at least $1 \mathrm{~h}$ before or $2 \mathrm{~h}$ after breakfast. Post chemotherapy, emesis was treated prophylactically, with ondansetron or metoclopramide orally.

On day 1 of cycle 1 , blood samples $(5 \mathrm{ml})$ for analysis of temozolomide were collected in pre-chilled heparinised tubes at $10,20,30,60,90,120,150,180,240,360$ and $1320 \mathrm{~min}$ after administration of temozolomide, plasma was separated and $2 \mathrm{ml}$ was transferred to a plastic tube containing $0.1 \mathrm{ml}$ of $8.5 \%$ phosphoric acid. For analysis of paclitaxel, $5 \mathrm{ml}$ heparinised blood samples were taken pretreatment and at 90, 180, 185, 195, 210, 225, $240,270,300,360,420,540,1260$ and $1620 \mathrm{~min}$ from the start of infusion. Sampling for temozolomide pharmacokinetics was repeated on day 5 of cycle 1 . Determinations of concentrations of paclitaxel or temozolomide in plasma were performed by HPLC, as previously described (Siddiqui et al, 1997; Estlin et al, 1998).

\section{RESULTS}

\section{In vitro studies}

Against the two melanoma cell lines, paclitaxel and temozolomide had very different activity. Values for $\mathrm{IC}_{50}$ (mean \pm s.d.) for temozolomide $(835 \pm 110$ and $821 \pm 75 \mu \mathrm{M})$ and paclitaxel $(15.3 \pm 2.5 \mathrm{~nm}$ and $13.5 \pm 1.5 \mathrm{~nm})$ were similar for the DX3 and A375P cell lines. The cell lines were 30 - to 40 -fold more sensitive to epothilone $\mathrm{B}$, with $\mathrm{IC}_{50}$ values of $0.55 \pm 0.06$ and $0.31 \pm 0.05 \mathrm{~nm}$ against DX3 and A375P cells, respectively.

For the DX3 cell line, the combination of temozolomide with paclitaxel produced CI values ranging from 0.02 at a fractional effect (FE) of 0.65 to a CI of 0.4 at an FE of 0.95 . Corresponding values for the DX3 cells with temozolomide and epothilone B were $\mathrm{CI}=0.01(\mathrm{FE}=0.84)$ and $\mathrm{CI}=0.55(\mathrm{FE}=0.96)$. In the $\mathrm{A} 375 \mathrm{P}$ cell line, temozolomide plus paclitaxel produced a $\mathrm{CI}$ of 0.15 at an $\mathrm{FE}$ of 0.1 and 0.66 at an FE of 0.9. Corresponding values for the combination with epothilone in the $\mathrm{A} 375 \mathrm{P}$ cells were $\mathrm{CI}=0.07$ $(\mathrm{FE}=0.05)$ and $\mathrm{CI}=0.79(\mathrm{FE}=0.98)$. Taken together, these data suggest synergism of action of these drug combinations against these two melanoma cell lines.

\section{Clinical study}

A total of 22 patients (13 male and nine female subjects) with a median age of 52.5 years (range 29-69 years) were recruited into the clinical study (Table 1). Patients received a total of 61 cycles of the combination chemotherapy, with an average of 2.8 cycles per patient. A total of 17 patients were assessable for toxicities and 15 patients were assessable for disease response. Six dose levels were explored (Figure 1).

Four patients were withdrawn from the study due to development of brain metastases within 28 days of enrolment. One patient was consented and did not receive treatment due to bleeding skin lesions and one patient progressed clinically and was taken off study after 22 days. One patient with apparently recurrent disease was found, on review of CT scans after six cycles of treatment, to have simple liver cysts.

Of the 17 patients assessable for toxicity, two experienced neutropaenia Grade 3 (Table 2). There was one episode of Grade 4 neutropaenia in a patient who also had Grade 3 thrombocytopaenia and anaemia. There were also two other cases of Grade 3 thrombocytopaenia. Patients 5 and 10 required a 50\% dose reduction in temozolomide due to hematological toxicity, with patient 11 requiring a $50 \%$ dose reduction in both drugs. Nonhematological toxicities included arthralgia, nausea and vaginal thrush. Two patients experienced an allergic reaction to Taxol, but in only one of these did this limit treatment.

Of the 15 patients assessable for response, there were two partial responses. Patient 1 , who had primary disease in the gall bladder with liver secondaries, showed a sustained response with no evidence of progressive disease after nine cycles. At 4 years after starting the trial, the patient remains well with only minimal evidence of liver disease. Patient 206, whose primary site was the skin of the left shoulder, with some deposits in the left axiliary lymph node, was treated initially on dose level 6 . She had a partial response after two cycles, which was sustained on CT scan after a further four cycles of treatment. This patient subsequently suffered

Table I Patient summary

\begin{tabular}{|c|c|c|c|c|}
\hline Patient & Dose level & Gender & Age (years) & Clinical outcome \\
\hline 1 & । & $\mathrm{F}$ & 51 & Excellent response to treatment, had nine cycles \\
\hline 2 & । & $\mathrm{F}$ & 62 & PD after C2 \\
\hline 3 & । & $\mathrm{F}$ & 57 & PD after C4 \\
\hline 4 & 2 & M & 31 & Withdrawn due to brain metastases \\
\hline 5 & 2 & $\mathrm{~F}$ & 41 & Improvement in $\mathrm{CT}$ after $\mathrm{C} 3$, but PD after $\mathrm{C} 5$ \\
\hline 6 & 2 & M & 55 & PD after 22 days \\
\hline 7 & 2 & $M$ & 37 & After C6, MRI revealed cysts and no cancer \\
\hline 8 & 3 & M & 55 & PD after 31 days \\
\hline 9 & 3 & M & 52 & PD after C2 \\
\hline 10 & 4 & $\mathrm{~F}$ & 50 & Minor response after C3. Withdrawn due to G4 thrombocytopenia after C4 \\
\hline|| & 4 & $\mathrm{~F}$ & 52 & Stopped after C2 due to haematoxocity and allergic reaction to taxol \\
\hline 12 & 4 & $\mathrm{~F}$ & 66 & PD after C3 \\
\hline 201 & 4 & M & 65 & PD after C2 \\
\hline 13 & 4 & $\mathrm{~F}$ & 38 & Withdrawn due to brain metastases after $\mathrm{C} 3$ \\
\hline 14 & 4 & M & 29 & Not given treatment, bleeding lesion \\
\hline 202 & 4 & M & 53 & PD after C2 \\
\hline 203 & 5 & M & 68 & Withdrawn due to brain metastases after $\mathrm{Cl}$ \\
\hline 204 & 5 & M & 63 & SD after $\mathrm{C} 2$ and $\mathrm{C} 4$, but withdrawn due to brain metastases after $\mathrm{C} 4$ \\
\hline 205 & 5 & M & 54 & Withdrawn due to brain metastases after $\mathrm{Cl}$ \\
\hline 206 & 6 & $\mathrm{~F}$ & 52 & PR after C3, had six cycles in total \\
\hline 20 & 6 & M & 41 & PD after $\mathrm{C2}$ \\
\hline 21 & 6 & M & 69 & PD after C2 \\
\hline
\end{tabular}

Patients were recruited at two centres, with different patient number schemes at each center. PD = progressive disease; $\mathrm{C} 2=$ course 2 , etc.; $\mathrm{CT}=$ computerised tomography scan; $\mathrm{MRI}=$ magnetic resonance imaging scan; $\mathrm{G} 4=$ Grade 4, etc., $M=$ male; $F=$ female; $P R=$ partial response; $S D=$ stable disease. 
Table 2 Haematological and nonhaematological toxicity by dose level

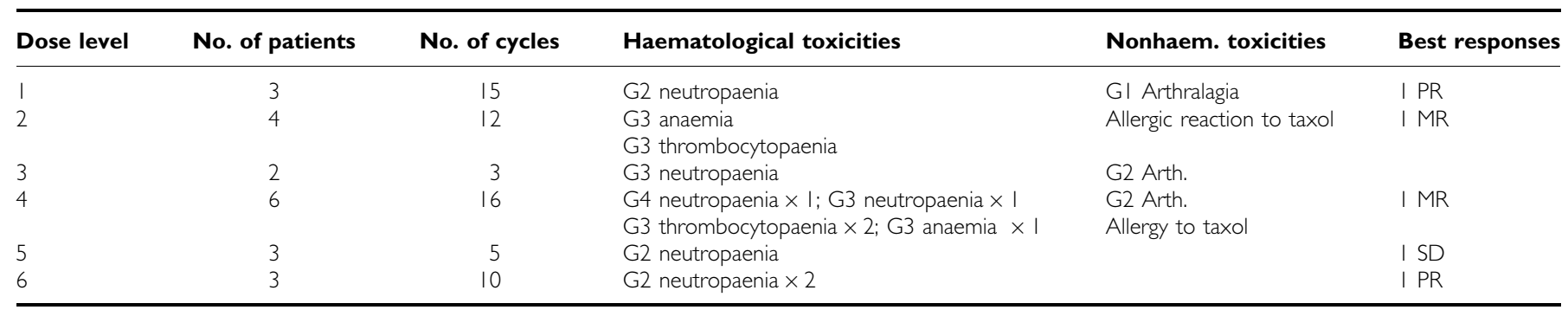

$\mathrm{PR}=$ partial response; $\mathrm{MR}=$ mixed response; $\mathrm{SD}=$ stable disease

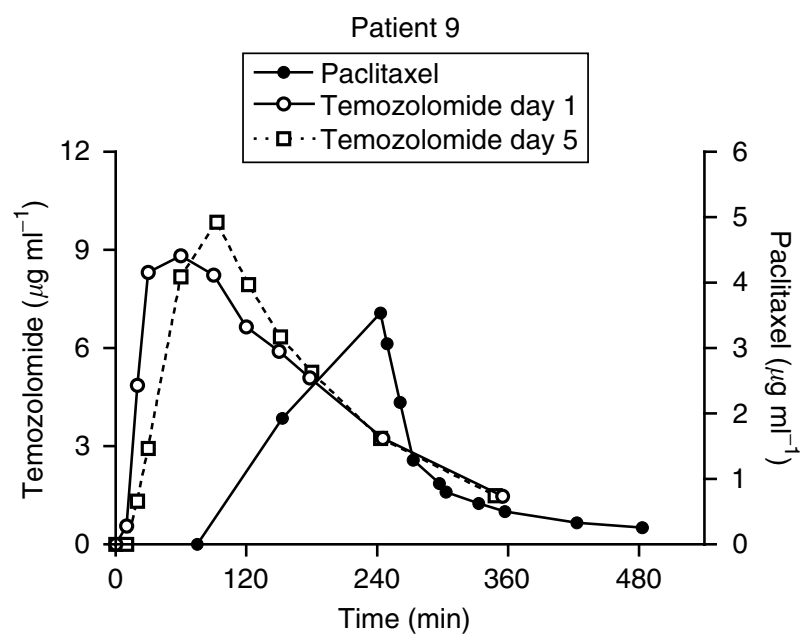

Figure 2 Time course of temozolomide (left axis) and paclitaxel (right axis) plasma concentrations on day I of therapy. The oral dose of temozolomide was administered first, with the $3 \mathrm{~h}$ infusion of paclitaxel started 60 min later. Data from day 5 administration of temozolomide are superimposed for comparison.

a recurrence of disease 3 months after the end of treatment, received radiotherapy and further chemotherapy including single agent temozolomide, but died of disease progression nearly 2 years after entry into this trial. In addition, patient 5 at dose level 2 and patient 10 at dose level 4 had mixed or minor responses. Patient 204 had stable disease up to course 4 , but was withdrawn from study due to brain metastases.

\section{Pharmacokinetic studies}

Temozolomide was administered at three different doses $(100,150$ and $200 \mathrm{mg} \mathrm{m}^{-2}$ day $\left.^{-1}\right)$. Although four patients were treated with $150 \mathrm{mg} \mathrm{m}^{-2}$ day $^{-1}$ temozolomide (combined with $150 \mathrm{mg} \mathrm{m}^{-2}$ paclitaxel), reliable pharmacokinetic data for temozolomide were available from only one patient. One patient on dose level 3 at $200 \mathrm{mg} \mathrm{m}^{-2}$ day $^{-1}$ had anomalous data, with increasing plasma concentrations throughout the sampling period. A representative graph of temozolomide and paclitaxel plasma concentrations in a patient treated at dose level 3 is shown in Figure 2.

There was no significant difference among the estimates of halflife, $\mathrm{Cl} / \mathrm{F}$ or $\mathrm{Vz} / \mathrm{F}$ for temozolomide at these different doses of temozolomide (Table 3), with an apparent dose-linear increase in AUC comparing doses between 100 and $200 \mathrm{mg} \mathrm{m}^{-2}$ (Table 3). The different doses of paclitaxel $\left(150,175,200\right.$ and $\left.225 \mathrm{mg} \mathrm{m}^{-2}\right)$ administered in conjunction with the highest dose of temozolomide $\left(200 \mathrm{mg} \mathrm{m}^{-2}\right)$ did not appear to influence the pharmacoki- netics of the latter drug (data not shown). Comparing the pharmacokinetics of temozolomide on day 1 (with paclitaxel) and day 5 (without paclitaxel), there was no difference in $C_{\max }$ or AUC between the 2 days of study (Table 3 ).

A summary of the pharmacokinetic data for paclitaxel at each of four dose levels is given in Table 4. Clearance of paclitaxel was greater at the lowest dose level of $150 \mathrm{mg} \mathrm{m}^{-2}\left(608 \pm 211 \mathrm{ml} \mathrm{min}^{-1}\right.$, all patients dose levels 1-3), compared to that observed at 175$225 \mathrm{mg} \mathrm{m}^{-2}\left(373 \pm 100\right.$ to $\left.363 \pm 120 \mathrm{ml} \mathrm{min}^{-1}\right)$. For dose levels $1-3$, where the paclitaxel dose was held constant, but the dose of temozolomide varied from 100 to $200 \mathrm{mg} \mathrm{m}^{-2} \mathrm{day}^{-1}$, there appears to be an increase in paclitaxel clearance as the dose of temozolomide was escalated (Table 4). However, the numbers of patients at each dose level are small and one-way analysis of variance on the log-transformed data indicated no significant effect. Comparison of paclitaxel clearance from patients in the current study with those from previously published studies suggests that those patients at dose level 1 have an unusually low clearance, while clearance values in patients at dose level 3 are larger than expected (see below).

\section{DISCUSSION}

This investigation combines in vitro studies of temozolomide and tubulin binding drugs with a Phase I clinical study of temozolomide and paclitaxel in melanoma. Interest in the use of these two agents in melanoma has been stimulated by their single-agent activities (Wiernik and Einzig, 1993) and nonoverlapping toxicities and mechanisms of resistance.

In vitro studies in two melanoma cell lines showed sensitivity to temozolomide and paclitaxel in line with reported $\mathrm{IC}_{50}$ values for a variety of other cell lines. Sensitivity to temozolomide is reported to depend on the activity of the repair enzyme $O^{6}$-alklyguanine alkyltransferase (ATase) and on mismatch repair (MMR) function (Pepponi et al, 2003). While the MMR status of these cell lines is not known, the relatively high $\mathrm{IC}_{50}$, coupled with the low ATase activity of the $\mathrm{A} 375 \mathrm{P}$ cell line ( $95 \mathrm{fmol} \mathrm{mg}^{-1}$ protein) (Wedge et al, 1997), may suggest a deficiency in MMR. Many tumour cells have only a moderate sensitivity to temozolomide ( $\mathrm{IC}_{50}$ around $10-$ $1000 \mu \mathrm{M}$ ) (Taverna et al, 2000; Pepponi et al, 2003), with a greater degree of sensitivity to paclitaxel ( $\mathrm{IC}_{50} 1-10 \mathrm{nM}$ ) (Rowinsky and Donehower, 1995; Lamendola et al, 2003). Resistance of melanoma cell lines to temozolomide is associated with deficiencies in mismatch repair and/or high activity of the repair enzyme $O^{6}$ alkylguanine-DNA alkyltransferase (Pepponi et al, 2003). Interestingly, these two melanoma cell lines were also sensitive to epothilone $\mathrm{B}\left(\mathrm{IC}_{50} 0.3\right.$ and $\left.0.5 \mathrm{~nm}\right)$. In a Phase I study of epothilone $\mathrm{B}$, plasma concentrations exceeded $1 \mathrm{nM}$ for approximately $8 \mathrm{~h}$ (Rothermel et al, 2003).

The combination studies with temozolomide and either paclitaxel or epothilone B showed strong signs of synergy. At the higher dose combinations used, effectively all of the cells were 
Table 3 Temozolomide pharmacokinetic parameters

\begin{tabular}{|c|c|c|c|c|c|}
\hline Dose level & Half-life (min) & 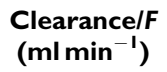 & $\begin{array}{c}\text { Volume of } \\
\text { distribution/F (I) }\end{array}$ & $\begin{array}{c}\text { AUC day I } \\
\left(\mu \mathrm{g} \mathrm{ml}^{-1} \mathrm{~min}^{-1}\right)\end{array}$ & $\begin{array}{c}\text { AUC day } 5 \\
\left(\mu \mathrm{g} \mathrm{ml}^{-1} \mathrm{~min}^{-1}\right)\end{array}$ \\
\hline $\begin{array}{l}\text { I }(n=3)\left(100 \mathrm{mg} \mathrm{m}^{-2} \mathrm{day}^{-1}\right) \\
2(n=1)\left(150 \mathrm{mg} \mathrm{m}^{-2} \mathrm{day}^{-1}\right) \\
3-6(n=14)\left(200 \mathrm{mg} \mathrm{m}^{-2} \mathrm{day}^{-1}\right)\end{array}$ & $\begin{array}{l}98 \pm 20 \\
241 \\
122 \pm 55\end{array}$ & $\begin{array}{l}157 \pm 10 \\
157 \\
188 \pm 55\end{array}$ & $\begin{array}{l}22.2 \pm 5.9 \\
54 \\
30.5 \pm 5.5\end{array}$ & $\begin{array}{l}1064 \pm 3 \\
1501 \\
2106 \pm 608\end{array}$ & $1946 \pm 580(n=11)$ \\
\hline
\end{tabular}

F indicates bioavailability, which is not determined here. AUC is the area under the plasma concentration-time curve. ${ }^{a}$ Data available on only one patient at this dose level. One patient at $200 \mathrm{mg} \mathrm{m}^{-2}$ day $^{-1}$ had anomalous data, with increasing plasma concentrations throughout the sampling period.

Table 4 Paclitaxel pharmacokinetic parameters

\begin{tabular}{|c|c|c|c|c|}
\hline Dose level & Half-life (min) & Clearance $\left(\mathrm{ml} \mathrm{min}^{-1}\right)$ & Volume of distribution (litres) & AUC $\left(\mu \mathrm{g} \mathrm{ml}^{-1} \min ^{-1}\right)$ \\
\hline ( $\left(150 \mathrm{mg} \mathrm{m}^{-2}\right)$ & 470,522 & 364,430 & 247,324 & 632,600 \\
\hline $2\left(150 \mathrm{mg} \mathrm{m}^{-2}\right)$ & 502,383 & 652,513 & 473,283 & 359,480 \\
\hline $3\left(150 \mathrm{mg} \mathrm{m}^{-2}\right)$ & $550,412,105^{a}$ & $779,909,505^{a}$ & $619,540,76^{\mathrm{a}}$ & $385,300,523^{a}$ \\
\hline $4\left(175 \mathrm{mg} \mathrm{m}^{-2}\right)$ & $410 \pm 74$ & $373 \pm 100$ & $216 \pm 53$ & $858 \pm 255$ \\
\hline $5\left(200 \mathrm{mg} \mathrm{m}^{-2}\right)$ & $495,198^{a}$ & $320,717^{a}$ & $228,205^{\mathrm{a}}$ & $1162,544^{a}$ \\
\hline $6\left(225 \mathrm{mg} \mathrm{m}^{-2}\right)$ & $298 \pm 87$ & $363 \pm 120$ & $152 \pm 63$ & $1220 \pm 416$ \\
\hline
\end{tabular}

a Data only to $8 \mathrm{~h}$.

killed. The mechanism of such synergy may relate to the mitotic block following paclitaxel or epothilone B treatment. It has been suggested that cells become apoptotic following escape from G2M blockade, and it may be that such cells are then sensitised to the actions of alkylating agents such as temozolomide. Previous studies have indicated additive effects of alkylating agents with paclitaxel (Liebmann et al, 1994). Combinations of temozolomide with tubulin binders such as the agents studied here have not been reported previously and may show useful activity in other tumour types. Although only two melanoma cell lines were studied, the activity of these agents in combination, at clinically relevant concentrations, indicates that further evaluation is warranted.

The clinical study, with a dose escalation of temozolomide followed by escalation of paclitaxel, showed that in combination both drugs could be given at full therapeutic doses. Indeed, the toxicity experienced was relatively mild even at the highest dose of paclitaxel $\left(225 \mathrm{mg} \mathrm{m}^{-2}\right)$ permitted by the protocol. Although grade 3 and 4 toxicities were observed at dose level $4\left(200 \mathrm{mg} \mathrm{m}^{-2} \mathrm{day}^{-1}\right.$ temozolomide $+175 \mathrm{mg} \mathrm{m}^{-2}$ paclitaxel), none occurred at the subsequent higher dose levels. There was some evidence of cumulative toxicity, with patient 10 at dose level 4 withdrawn from treatment due to Grade 4 thrombocytopaenia after course 4. Further dose escalation may be possible, but the clinical benefit of this is unknown. A number of patients gained some clinical benefit from treatment with temozolomide and paclitaxel. Patient 1 showed a good response and went on to receive nine courses of treatment, remaining well on long-term follow-up. Patient 10 had a minor response and patient 206 had a partial response after course 3 , receiving six courses in total. Patient 7 received six courses of treatment for what appeared to be a recurrence of liver metastases. However, liver scans revealed the presence of benign cysts. In this Phase I study, the primary aim was to determine the safety of temozolomide and paclitaxel in combination. Nevertheless, the level of activity observed, over a range of dose levels, is promising.

Other clinical studies of a combination of a taxane with monofunctional alkylating agent have been reported. Paclitaxel has been given at doses up to $250 \mathrm{mg} \mathrm{m}^{-2}$ with DTIC up to $1000 \mathrm{mg} \mathrm{m}^{-2}$. This combination was well tolerated, but did not show a higher response rate than either agent used alone (Feun et al, 2002). Similarly, docetaxel has been combined with DTIC, but again the response rate was not dissimilar to single-agent therapy (Bafaloukos et al, 2002a). The combination of temozolomide with docetaxel has recently been reported to be safe and to have good activity in a Phase II study (Bafaloukos et al, 2002b). Dacarbazine may not be a good drug for use in these combinations as it requires metabolic activation, which may be inhibited by coadministered drugs such as the taxanes.

Recent clinical studies in malignant melanoma have explored other schedules and combinations of these two drugs. Temozolomide has been combined with thalidomide (Hwu et al, 2003) or with interferon- $\alpha$, using schedules similar to that used here, or with daily or three-times daily administration for 6 weeks out of eight. Most promising results have been obtained in combination with thalidomide (Danson et al, 2003), but that combination requires further investigation. Paclitaxel has been investigated on a weekly schedule (Zimpfer-Rechner et al, 2003) or every 4 days for three doses in a three week cycle. The latter schedule produced a $15 \%$ response rate (Bedikian et al, 2004). Combinations with carboplatin have also been investigated, but with no therapeutic benefit (Zimpfer-Rechner et al, 2003). Given the results presented here, exploration of other schedules for both drugs may be beneficial.

The combination of temozolomide with paclitaxel involves the administration of one drug orally, while the other is given by a continuous $3 \mathrm{~h}$ infusion. The relative timings of the two drugs may be governed by clinical concerns, such as withholding the oral drug in case a hypersensitivity reaction is seen to the intravenous one. Hypersensitivity reactions were seen in only two patients in this study. Regardless of the order of administration, there is no $a$ priori reason to suspect a pharmacokinetic interaction between temozolomide and paclitaxel. One is eliminated almost entirely by a spontaneous chemical reaction, while the other is subject to metabolism, mediated by CYP450 enzymes, and to biliary excretion.

The pharmacokinetic parameters derived for temozolomide in combination with paclitaxel were very similar to those reported previously for temozolomide alone (Jen et al, 2000). Also, there was no evidence of nonlinearity of pharmacokinetics as the dose of temozolomide was increased and no effect of increasing the concurrent dose of paclitaxel from 150 to $225 \mathrm{mg} \mathrm{m}^{-2}$. Although at the lowest dose level of paclitaxel $\left(150 \mathrm{mg} \mathrm{m}^{-2}\right)$ there did appear to be an increase in clearance with increasing dose of temozolomide $\left(100-200 \mathrm{mg} \mathrm{m}^{-2} \mathrm{day}^{-1}\right)$, this was not statistically significant. Previous studies with paclitaxel at a dose of $150 \mathrm{mg} \mathrm{m}^{-2}$ indicated a clearance of $588 \pm 31 \mathrm{ml} \mathrm{min}^{-1}$ (Siddiqui et al, 1997), almost identical to that reported at dose level 2. At dose level 3, the two patients with full paclitaxel data had unusually high clearances, but 
the third patient, in whom data were available only to $8 \mathrm{~h}$, had an approximate clearance value nearer to that expected. There was no evidence of increased clearance of paclitaxel in combination with the same dose of temozolomide at dose level 4. The expected phenomenon of apparent decrease in clearance with increasing dose of paclitaxel was observed, which may cloud the interpretation of any apparent interaction. This apparent nonlinearity in pharmacokinetics is now known to be due to the action of the solubilising agent Cremophor, which sequesters paclitaxel in a dose-dependent manner (van Zuylen et al, 2001). In conclusion, in the absence of a within patient crossover study, there appears to be no pharmacokinetic interaction between temozolomide and paclitaxel when given in combination.

The in vitro data presented here indicate that the combination of temozolomide with the microtubule agent epothilone $\mathrm{B}$ or paclitaxel produces a synergistic inhibition of tumour cell growth.

\section{REFERENCES}

Arbuck SG, Christian MC, Fisherman JS, Cazenave LA, Sarosy G, Suffness M, Adams J, Canetta R, Cole KE, Friedman MA (1993) Clinical development of Taxol. J Natl Cancer Instit Monogr 15: 11-24

Bafaloukos D, Aravantinos G, Fountzilas G, Stathopoulos G, Gogas H, Samonis G, Briasoulis E, Mylonakis N, Skarlos DV, Kosmidis P (2002a) Docetaxel in combination with dacarbazine in patients with advanced melanoma. Oncology 63: 333-337

Bafaloukos D, Gogas H, Georgoulias V, Briassoulis E, Fountzilas G, Samantas E, Kalofonos C, Skarlos D, Karabelis A, Kosmidis P (2002b) Temozolomide in combination with docetaxel in patients with advanced melanoma: a phase II study of the Hellenic Cooperative Oncology Group. J Clin Oncol 20: $420-425$

Baker SD, Wirth M, Statkevich P, Reidenberg P, Alton K, Sartorius SE, Dugan M, Cutler D, Batra V, Grochow LB, Donehower RC, Rowinsky EK (1999) Absorption, metabolism, and excretion of 14C-temozolomide following oral administration to patients with advanced cancer. Clin Cancer Res 5: 309-317

Balch CM, Soong SJ, Gershenwald JE, Thompson JF, Reintgen DS, Cascinelli N, Urist M, McMasters KM, Ross MI, Kirkwood JM, Atkins MB, Thompson JA, Coit DG, Byrd D, Desmond R, Zhang Y, Liu PY, Lyman GH, Morabito A (2001) Prognostic factors analysis of 17,600 melanoma patients: validation of the American Joint Committee on Cancer melanoma staging system. J Clin Oncol 19: 3622-3634

Bedikian AY, Plager C, Papadopoulos N, Eton O, Ellerhorst J, Smith T (2004) Phase II evaluation of paclitaxel by short intravenous infusion in metastatic melanoma. Melanoma Res 14: 63-66

Bleehen NM, Newlands ES, Lee SM, Thatcher N, Selby P, Calvert AH, Rustin GJ, Brampton M, Stevens MF (1995) Cancer Research Campaign phase II trial of temozolomide in metastatic melanoma. J Clin Oncol 13: $910-913$

Brada M, Judson I, Beale P, Moore S, Reidenberg P, Statkevich P, Dugan M, Batra V, Cutler D (1999) Phase I dose-escalation and pharmacokinetic study of temozolomide (SCH 52365) for refractory or relapsing malignancies. Br J Cancer 81: $1022-1030$

Chou TC, Hayball MP (1996) CalcuSyn: Windows Software for Dose Effect Analysis. BIOSOFT: Cambridge, UK

Danson S, Lorigan P, Arance A, Clamp A, Ranson M, Hodgetts J, Lomax L, Ashcroft L, Thatcher N, Middleton MR (2003) Randomized phase II study of temozolomide given every $8 \mathrm{~h}$ or daily with either interferon alfa-2b or thalidomide in metastatic malignant melanoma. J Clin Oncol 21: $2551-2557$

D’Atri S, Tentori L, Lacal PM, Graziani G, Pagani E, Benincasa E, Zambruno G, Bonmassar E, Jiricny J (1998) Involvement of the mismatch repair system in temozolomide-induced apoptosis. Mol Pharmacol 54: $334-341$

Denny BJ, Wheelhouse RT, Stevens MF, Tsang LL, Slack JA (1994) NMR and molecular modeling investigation of the mechanism of activation of the antitumor drug temozolomide and its interaction with DNA. Biochemistry 33: $9045-9051$

Dhodapkar M, Rubin J, Reid JM, Burch PA, Pitot HC, Buckner JC, Ames MM, Suman VJ (1997) Phase I trial of temozolomide (NSC 362856) in patients with advanced cancer. Clin Cancer Res 3: $1093-1100$
The clinical study of the combination of temozolomide with paclitaxel shows that this combination is well tolerated, not complicated by any pharmacokinetic interaction and has modest activity in a Phase I setting. Although the response rate in this Phase I study was not dissimilar to that of the individual agents, the combination of the two drugs at full therapeutic doses could be investigated further. Combinations of temozolomide with epothilone B may also be beneficial, but require initial clinical evaluation.

\section{ACKNOWLEDGEMENTS}

This research was supported by Cancer Research UK, and by the Libyan Government. Epothilone B was a kind gift from Novartis, Basle, Switzerland.
Einzig AI, Hochster H, Wiernik PH, Trump DL, Dutcher JP, Garowski E, Sasloff J, Smith TJ (1991a) A phase II study of taxol in patients with malignant melanoma. Invest New Drugs 9: 59-64

Einzig AI, Wiernik PH, Schwartz EL (1991b) Taxol: a new agent active in melanoma and ovarian cancer. Cancer Treat Res 58: 89-100

Estlin EJ, Lashford L, Ablett S, Price L, Gowing R, Gholkar A, Kohler J, Lewis IJ, Morland B, Pinkerton CR, Stevens MC, Mott M, Stevens R, Newell DR, Walker D, Dicks-Mireaux C, McDowell H, Reidenberg P, Statkevich P, Marco A, Batra V, Dugan M, Pearson AD (1998) Phase I study of temozolomide in paediatric patients with advanced cancer. United Kingdom Children's Cancer Study Group. Br J Cancer 78: $652-661$

Ettinger DS (1993) Overview of paclitaxel (Taxol) in advanced lung cancer. Semin Oncol 20: $46-49$

Feun LG, Savaraj N, Hurley J, Marini A (2002) Phase II trial of paclitaxel and dacarbazine with filgrastim administration in advanced malignant melanoma. Cancer Invest 20: 357-361

Horwitz SB (1994) Taxol (paclitaxel): mechanisms of action. Ann Oncol 5: S3-S6

Hwu WJ, Krown SE, Menell JH, Panageas KS, Merrell J, Lamb LA, Williams LJ, Quinn CJ, Foster T, Chapman PB, Livingston PO, Wolchok JD, Houghton AN (2003) Phase II study of temozolomide plus thalidomide for the treatment of metastatic melanoma. J Clin Oncol 21: 3351-3356

Jen JF, Cutler DL, Pai SM, Batra VK, Affrime MB, Zambas DN, Heft S, Hajian G (2000) Population pharmacokinetics of temozolomide in cancer patients. Pharmaceut Res 17: 1284-1289

Lamendola DE, Duan ZF, Yusuf RZ, Seiden MV (2003) Molecular description of evolving paclitaxel resistance in the SKOV-3 human ovarian carcinoma cell line. Cancer Res 63: 2200-2205

Lee SM, Thatcher N, Crowther D, Margison GP (1994) Inactivation of $O^{6}$-alkylguanine-DNA alkyltransferase in human peripheral blood mononuclear cells by temozolomide. Br J Cancer 69: 452-456

Legha SS, Ring S, Papadopoulos N, Raber M, Benjamin RS (1990) A phase II trial of taxol in metastatic melanoma. Cancer 65: 2478-2481

Liebmann JE, Fisher J, Teague D, Cook JA (1994) Sequence dependence of paclitaxel (Taxol(R)) combined with cisplatin or alkylators in human cancer cells. Oncol Res 6: 25-31

Lotze MT, Dallal RM, Kirkwood JM, C FJ (2001) Cutaneous melanoma. In Cancer: Principles \& Practice of Oncology Rosenberg SA, DeVita VT, Hellman S (eds) London, Philadelphia: Lippincott-Raven

Martin V (1993) Overview of paclitaxel (TAXOL). Semin Oncol Nurs 9: 2 - 5 Middleton MR, Grob JJ, Aaronson N, Fierlbeck G, Tilgen W, Seiter S, Gore M, Aamdal S, Cebon J, Coates A, Dreno B, Henz M, Schadendorf D, Kapp A, Weiss J, Fraass U, Statkevich P, Muller M, Thatcher N (2000a) Randomized phase III study of temozolomide versus dacarbazine in the treatment of patients with advanced metastatic malignant melanoma. J Clin Oncol 18: 158-166

Middleton MR, Lee SM, Arance A, Wood M, Thatcher N, Margison GP (2000b) $O^{6}$-methylguanine formation, repair protein depletion and clinical outcome with a $4 \mathrm{~h}$ schedule of temozolomide in the treatment of advanced melanoma: results of a phase II study. Int J Cancer 88: $469-473$ 
Middleton MR, Lunn JM, Morris C, Rustin G, Wedge SR, Brampton MH, Lind MJ, Lee SM, Newell DR, Bleehen NM, Newlands ES, Calvert AH, Margison GP, Thatcher N (1998) $O^{6}$-methylguanine-DNA methyltransferase in pretreatment tumour biopsies as a predictor of response to temozolomide in melanoma. Br J Cancer 78: 1199-1202

Newlands ES, Blackledge GR, Slack JA, Rustin GJ, Smith DB, Stuart NS, Quarterman CP, Hoffman R, Stevens MF, Brampton MH (1992) Phase I trial of temozolomide (CCRG 81045: M\&B 39831: NSC 362856). Br J Cancer 65: 287-291

O'Reilly SM, Newlands ES, Glaser MG, Brampton M, Rice-Edwards JM, Illingworth RD, Richards PG, Kennard C, Colquhoun IR, Lewis P (1993) Temozolomide: a new oral cytotoxic chemotherapeutic agent with promising activity against primary brain tumours. Eur J Cancer 29A: $940-942$

Pepponi R, Marra G, Fuggetta MP, Falcinelli S, Pagani E, Bonmassar E, Jiricny J, D'Atri S (2003) The effect of O-6-alkylguanine-DNA alkyltransferase and mismatch repair activities on the sensitivity of human melanoma cells to temozolomide, 1,3-bis(2-chloroethyl)-1nitrosourea, and cisplatin. J Pharmacol Exp Therapeut 304: 661-668

Rothermel J, Wartmann M, Chen T, Hohneker J (2003) EPO906 (epohtilone B): a promising novel microtubule stabilizer. Semin Oncol 30: $51-55$

Rowinsky EK, Cazenave LA, Donehower RC (1990) Taxol: a novel investigational antimicrotubule agent. J Natl Cancer Instit 82: 1247-1259

Rowinsky EK, Donehower RC (1995) Paclitaxel (taxol). N Engl J Med 332: $1004-1014$
Selzer E, Schlagbauer-Wadl H, Okamoto I, Pehamberger H, Potter R, Jansen B (1998) Expression of Bcl-2 family members in human melanocytes, in melanoma metastases and in melanoma cell lines. Melanoma Res 8: $197-203$

Siddiqui N, Boddy AV, Thomas HD, Bailey NP, Robson L, Lind MJ, Calvert AH (1997) A clinical and pharmacokinetic study of the combination of carboplatin and paclitaxel for epithelial ovarian cancer. Br J Cancer 75: 287-294

Taverna P, Liu L, Hanson AJ, Monks A, Gerson SL (2000) Characterization of MLH1 and MSH2 DNA mismatch repair proteins in cell lines of the NCI anticancer drug screen. Cancer Chemother Pharmacol 46: 507-516 van Zuylen L, Karlsson MO, Verweij J, Brouwer E, de Bruijn P, Nooter K, Stoter G, Sparreboom A (2001) Pharmacokinetic modelling of paclitaxel encapsulation in Cremophor EL micelles. Cancer Chemother Pharmacol 47: 309-318

Wedge SR, Porteous JK, Newlands ES (1997) Effect of single and multiple administration of an O-6-benzylguanine/temozolomide combination: an evaluation in a human melanoma xenograft model. Cancer Chemoth Pharmacol 40: $266-272$

Wiernik PH, Einzig AI (1993) Taxol in malignant melanoma. J Natl Cancer Instit Monogr 15: 185-187

Zimpfer-Rechner C, Hofmann U, Figl R, Becker JC, Trefzer U, Keller I, Hauschild A, Schadendorf D (2003) Randomized phase II study of weekly paclitaxel versus paclitaxel and carboplatin as second-line therapy in disseminated melanoma: a multicentre trial of the Dermatologic Cooperative Oncology Group (DeCOG). Melanoma Res 13: 531-536 